\title{
On the Differential Effects of Individual and Collaborative Written Corrective Feedback on the Accuracy of Iranian Female EFL Learners' Writing
}

\author{
Alireza Bonyadi ${ }^{1}$, Lachin Jafari ${ }^{1}$ \\ ${ }^{1}$ English Dept., Urmia Branch, Islamic Azad University, Urmia, Iran \\ Correspondence: Alireza Bonyadi, English Dept., Urmia Branch, Islamic Azad University, Urmia, Iran.
}

Received: September 27, 2018 Accepted: October 20, 2018 Online Published: November 27, 2018

doi:10.11114/ijecs.v1i2.3657

URL: https://doi.org/10.11114/ijecs.v1i2.3657

\begin{abstract}
This paper aimed at examining the differential effects of individual and collaborative written corrective feedbacks on EFL learners' writing accuracy. To this end, 60 female English language learners were selected from among 80 students of intermediate EFL learners in private language institute in Urmia (West Azerbayjan, IRI). The participants were randomly divided into two groups namely, 'individual feedback group' and 'collaborative feedback group'. Two different correction procedures were provided for both groups. For the first group, the assignment papers of the participants was gathered by the instructor in order to be provided with explicit written corrective feedback for their writings in terms of grammar and mechanics, while for the second group, six participants wrote on a topic and each composition was corrected by four EFL learners. Finally, a post-test on writing was conducted for both groups, and a $\mathrm{t}$-test analysis was used to compare the mean scores of both groups. The findings of the study revealed that there was a significant difference between the individual and collaborative corrective feedback groups in terms of their writing accuracy.
\end{abstract}

Keywords: EFL learners, collaborative feedback, individual feedback, written corrective feedback, writing accuracy

\section{Introduction}

Writing skill is regarded as the most complicated and prominent skill in second and foreign language acquisition (Brown, 2007). For Richards and Renandya (2002), writing skill seems to be problematic in language learning since it engages in not only in "generating and organizing of ideas but also in translating these ideas into readable texts" (p. 303).

The importance of writing as an essential language skill urges the investigation and finding effective and influential techniques, methods and approaches to improve this skill in different contexts. James (1998) believes that finding techniques for boosting writing skill as well as finding effective techniques to correct learners' writing errors are the prominent concern of second or foreign language teachers and learners where a lot of people are involved in the process of writing for different aims and objectives.

Different researchers in this area have emphasized the role of corrective feedback in enhancing learners' writing skill. Ashwell (2000) ascertains that providing corrective feedback can help learners to make revisions in the final product of their writing which consequently leads to better L2 writing. In a similar manner, Bitchener (2008) overestimates the role of corrective feedback in foreign language learners' writing ability.

It seems that engaging the learners in collaborative activities is one of the ways to develop interaction in the writing class. Actually, it has been proven to be effective means of enhancing students' writing skill (Marzban, 2014). These interactive activities are of importance as they mediate language learning (lantof, 2000).

Justification for the use of collaborative writing is strongly found in four theoretical stances namely, 'process writing', 'collaborative learning', 'Vygotskian learning theory' and 'interactionist” theories of L2 acquisition' (Liu \& Hansen, 2002).

\subsection{Related Studies on Corrective Feedback}

There are some empirical studies on corrective feedback in general and written corrective feedback in particular reviewed and presented below. 
Chandler's (2003, as cited in Corpuz, 2011) study on the effect of error correction on accuracy improvement of L2 student writing showed greater improvement in the accuracy of students who received error correction than of those who did not.

Bitchener (2008, as cited in Corpuz, 2011) also conducted a research on the effectiveness of written corrective feedback on ESL students' writing. The study aimed at scrutinizing whether corrective feedback on ESL student writing resulted in improved accuracy in L2 essay writing over a two-month period and to investigate whether there was a difference among different corrective feedback methods. Based on the findings the students who received written corrective feedback outperformed those in the control group.

In a study by Sarkhosh, Farahani, and Soleimani (2012) which examined the effect of corrective feedback on learners' immediate and delayed accuracy development, the findings revealed that the experimental groups who received different corrective feedback types outperformed the control group receiving no correction.

Farrokhi and Sattarpour (2012) studied the effect of feedback with sixty high-proficient L2 learners forming a control group and two experimental groups. One experimental group received focused written CF and the other experimental group received unfocused written $\mathrm{CF}$, while the control group received no feedback. The statistical analyses indicated that both experimental groups did better than control group in the post-test.

Ahmadi Shirazi and Shekarabi (2014) investigated the effect of direct and indirect feedback on the writing performance of Iranian learners of Japanese as a foreign language. Results showed that there is a significant difference between groups with the experimental group having a higher mean of accuracy in the use of three linguistic categories and that just direct feedback enhanced the linguistic aspect of written essays of students with indirect feedback having little or no role to play in writing practice.

In Farid and Samad's study (2012) three different treatment groups received three different types of direct feedback namely, 'direct feedback with written meta-linguistic explanation', 'direct feedback with oral meta-linguistic explanation', and 'direct feedback only'. The results of statistical analyses showed that all types of direct feedback were effective but different types of feedback can be ranked in terms of their importance.

Taking all the theoretical and empirical evidence highlighted above into account, it is apparent that the issue of the effectiveness of written error correction warrants further exploration. In addition, it can be inferred that previous studies on error correction have produced varying results because of differences in research design. Nevertheless, it can be argued that error correction should be continued unless its ineffectiveness and harmfulness has been conclusively proven.

\subsection{Related Studies on Collaborative Learning Strategy}

There are also some empirical studies on corrective feedback and written corrective feedback in particular which have been reviewed below.

Shull (2001) investigated the influence of using collaborative strategy on students' writing performance. The findings of this quasi experimental research indicated that using this strategy had a significant effect on students' writing performance.

In another empirical study, Fawcett and Garton (2005) focused on the effect of collaborative strategy on the problemsolving ability of students. Based on the results, students who participated in collaborative activities secured a higher performance than the students engaged in individual-based activities. The findings indicated that children who completed the activity collaboratively achieved a higher number of correct sorting than those who completed it individually.

In another study, Storch and Wigglesworth (2007) made an attempt to compare the individually-produced texts with pair-produced ones. The study reported a significant difference between the texts.

Soleimani (2014) examined the impact of collaborative peer corrective feedback and individual teacher corrective feedback on pre-intermediate Iranian EFL learners' writing performance. He divided the participants into two groups namely, collaborative peer correction and individual teacher correction groups. The researcher concluded that corrective written feedback provided by peers collaboratively was more effective in developing writing proficiency of Iranian EFL learners compared to the feedback provided by individual teacher.

Ballester and Cabello (2016) investigated English language learners' perception and preferences of collaborative activities for developing their writing ability. Their findings indicated that the percentage of students who accepted positive experiences working in collaborative writing tasks outnumbered the percentage of students who expressed their dissatisfaction working in these tasks.

In another recent study, Kahyalar and Y1lmaz (2016) investigated the effect of written corrective feedback on EFL 
learners' uptake. The aim of their study was to investigate whether collaborating with a peer in the editing process could have a positive impact on the students' uptake. The findings showed that the revision with a peer group (i.e. collaborative corrective feedback) made the students correct their grammatical and mechanical errors more successfully than those in individual revision group. However, the individual written corrective feedback group showed higher levels of uptake when corrective feedback on lexical errors was considered.

It seems that collaborative corrective feedback helps EFL learners to improve their writing skill. However, this reviewed literature reveals that there is not any particular study to investigate and compare the influence of individual and collaborative corrective feedback in Iranian EFL context at the same time. Besides, there is a controversy over the fruitfulness of collaborative corrective feedback, that is, researchers in the area of foreign language learning did not agree unanimously over the positive effect of collaborative corrective feedback on writing ability and different empirical studies highlight the need for further studies in this area. Thus, to fill the gap, the present study tries to compare their differential effects.

\section{Methodology}

\subsection{Research Question}

To investigate the differential effects of collaborative and individual written corrective feedback on Iranian EFL learners' writing accuracy, the following question was addressed and investigated in this study

1. Is there a significant statistical difference between collaborative and individual written corrective feedback in terms of their effect on writing accuracy of Iranian female EFL learners?

\subsection{Research Design}

The present study is a quasi-experimental study. It encompasses both dependent and independent variables. The dependent variable is EFL learners' writing accuracy, while the independent variables are collaborative and individual written corrective feedback. The justification behind selecting this type of research traces back to the aim of the study, that is, it aims at examining the effect of independent variable on the dependent variable after the treatment. Simple random sampling was used to select and divide the participants into two experimental groups. The scores which were obtained from the post-test were used to operationalize the dependent variable, i.e. EFL learners' writing accuracy.

\subsection{Participants}

In order to conduct the present study, sixty EFL learners, between the ages of 14 and 18, were selected randomly out of the total population of 80 intermediate Iranian female EFL learners from private English language institute Urmia Branch (West Azerbayjan, Iran). They were all native speakers of Azeri language including only females. Having established homogeneity among the participants in terms of their mother language, the researcher selected those participants whose mother language was Azari. These 60 chosen participants were randomly assigned to two experimental groups (i.e. one collaborative experimental group and one individual experimental group, 30 participants in each group).

\subsection{Instrumentation and Scoring System}

In order to carry out the investigation, a post-test which was based on the participants' course book, and checklist for scoring the participants' writing based on Anderson's Analytic scoring rubric were used. The post-test which were based on the participants' course book were administered to the participant of both experimental groups (i.e. collaborative written corrective feedback group and individual written corrective feedback group). The participants in both groups were asked to write on the same topics at the end of the study. The participants were supposed to write at least 80 words in 45 minutes.

Analytic scoring scale was used in the process of scoring. In this type of scoring, various facets of a piece of writing are scored separately. The justifications for selecting this scoring procedure are the ability to dispose the burden of uneven development of sub-skills, to consider various aspects of writing, and to make more reliable scoring. To this end, Anderson's analytic standard scoring checklist was utilized. Anderson's scoring checklist includes five general scales namely, 'fluency', 'form', 'grammar', 'vocabulary', and 'mechanics'; however, two scales namely, 'grammar' and 'mechanics' were used for scoring process in the present study to fulfill the purpose of the study and to compensate time limitation. Each of these scales was operationalized by six items. The points for the components ranges from 6 to 1 in a chronological order, and the total score ranged from at least 2 to at most 12.

\subsection{Research Procedure}

In the process of conducting the study, different steps were followed. It consisted nine sessions (one post-test, and eight sessions for the treatment). First of all, 60 Iranian female EFL learners were randomly selected out of the total population of 80 Intermediate EFL learners. The selected participants were randomly assigned into two experimental 
groups namely, 'individual written corrective feedback group' and 'collaborative written corrective feedback group'.

In the course of four weeks treatment, both groups attended to the classes two sessions per week. The participants in both groups were supposed to write one composition each session on general topics covered in their students' course books (e.g., describe your classmate, describe your English teacher, etc.). During writing time, the instructor monitored and observed learners and provided hints whenever needed. First half of the class time was allocated for writing task, while the second half of the class was devoted to correct the errors. However, two different correction procedure were provided for both groups, that is, for the first group (individual written corrective feedback), the assignment papers of the participants was gathered by the instructor in order to be provided with explicit written corrective feedback for their writings in terms of grammar and mechanics, while for the second group (collaborative written corrective feedback group), six participants wrote on a topic and each composition was corrected by four EFL learners. Thus, six heterogeneous groups of four members were formed by the instructor to correct one composition each session in collaborative group. In other words, each composition was corrected by a group of four heterogeneous groups collaboratively so that the manuscripts of six participants were corrected each session.

After the treatment, the participants in both groups were asked to write a short composition on two topics (i.e. describe your best trip, and, describe your best holyday). These two writing tasks were considered as the post-test of the study. The participants' manuscripts were scored by two raters based on Anderson's analytic rating scale in terms of grammar and mechanics. The interrater reliability for the post-test scores was 0.87 which was significant at 0.01 level. Finally, both descriptive and inferential statistical analyses were provided for the collected data.

\section{Results and Discussion}

To test the hypothesis of the study namely "there is no significant statistical difference between collaborative and individual written corrective feedback in terms of their effect on writing accuracy of Iranian female EFL learners", T-test was run. Table 1.1 shows the results of descriptive statistics for post-tests in both collaborative and individual written corrective feedback groups.

Table 1. Descriptive statistics for post-test scores in groups

\begin{tabular}{llll}
\hline \multicolumn{4}{l}{ Descriptive statistics for post-test scores in groups } \\
\hline Group & Mean & $\mathrm{N}$ & Standard Deviation \\
\hline Collaborative & 8.291 & 30 & 0.950 \\
\hline Individual & 6.866 & 30 & 1.108 \\
\hline
\end{tabular}

As Table 1 shows, mean score and standard deviation for collaborative written corrective feedback group are 8.291 and .950 , respectively. However, for individual written corrective feedback group, mean score and standard deviation are 6.866 and 1.108, respectively. A glance into the mean scores of both groups indicates a difference. However, a statistical analysis is used to check whether this difference is significant or not. Table 2 deals with the results of Levene's Test for Equality of Variances.

Table 2. T-test for both Groups in the Post-Test

\begin{tabular}{llllllll}
\hline \hline \multicolumn{1}{l}{$\begin{array}{l}\text { Levene's test for } \\
\text { equality of variances }\end{array}$} & & & & & \\
\cline { 2 - 6 } & difference & F. & Sig. & T. & df & 2_tailed Sig. & M. \\
\hline $\begin{array}{l}\text { Equal variances } \\
\text { assumed }\end{array}$ & 66 & .270 & -2.031 & 19 & .000 & 1.425 \\
\hline Sig $<0.05$ & & & & & & \\
\hline $\begin{array}{l}\text { Equal variances } \\
\text { not assumed }\end{array}$ & & & -2.031 & 18.41 & 1.425 \\
\hline
\end{tabular}

According to the results $(\mathrm{p}=0.00<0.05)$, there was significant difference between the mean scores of the two groups (collaborative and individual written corrective feedback groups) in the post-test scores. As a result, it can be inferred that collaborative written corrective feedback group outperformed individual written corrective feedback group. So, the null hypothesis was rejected. In other words, there is significant statistical difference between collaborative and individual written corrective feedback in terms of their effect on writing accuracy of Iranian female EFL learners.

The findings of the present study also indicated that using collaborative learning in terms of providing language learners with collaborative written corrective feedback improved EFL learners' writing accuracy.

In accordance with Shull's study (2001, as cited in Albesher, 2012) that showed students who involved in collaborative learning had improved more than those of students in the control group with traditional teacher-feedback technique, the present study has given a crucial role to collaborative corrective feedback type and reported an advantage of 
collaborative written corrective feedback in developing EL learners' writing accuracy in comparison with individual written corrective feedback which is widely used in Iranian EFL classes.

Additionally, this study has provided additional insights to those of other studies that have scrutinized the influence of collaborative learning in improving students' writing skills. For instance, Suzuki (2008) investigated differences between individual corrective feedback and group revisions of written compositions among adult ESL learners. Suzuki (2008) reported that students who used group revisions paid more attention to content and ideas, and improved their writing ability. Similarly, the findings of the present study supports the idea that collaborative corrective feedback has the ability to boost language learners' writing.

Also, the findings of the present study confirm the results of the studies done by Sarkhosh, Farahani, and Soleimani (2012) which investigated the effect of corrective feedback types on learners' accuracy development. The results indicated that the experimental groups who received different corrective feedback types outperformed the control group who received no correction. Existing theories can support the findings of this study from different aspects. First, noticing hypothesis proposed by Schmidt (1990) states that only the items which are noticed by the learners are mostly learnt. As a result, since error feedback attracts learners' attention towards the erroneous linguistic form, it will help them in taking the prerequisite step to develop their inter-language system. In other words, as corrective feedback draws learners' attention to their areas of difficulty and urges their minds to process language content, it can be advantageous.

The findings of the present study are also in line with the findings of Marzban (2014) who tried to explore the impact of collaborative feedback on Iranian intermediate EFL learners' writing and compared it with teacher feedback. While experimental group was provided with collaborative negotiated feedback, the control group was provided with the teacher's feedback during the sessions. Marzban (2014) came to this conclusion that participants of the experimental group, who were exposed to collaborative feedback, outperformed the other group. The triangulation of three different sources; Pre/Post-test comparison, the questionnaire and interviews provide evidences in support of the efficacy of Collaborative Feedback. The findings of the present study support the efficiency of collaborative feedback in enhancing EFL learners' performance in writing tasks.

However, there are other studies which are not in line with the findings of the present study. For example, the findings of the present study differ from those of Storch's study (2007), who investigated whether completing editing tasks in pairs would produce better results in terms of accuracy than completing them individually. Storch's results showed that students who worked in pairs took longer to complete the editing tasks than students who worked individually. She found also that the difference between the two groups was not statistically significant. In addition, this study is in contrast with Truscott (2007) who stated that accuracy developments may be due to learners' simplified writing and not because of the corrective feedback. On the other hand, the findings of the present study indicated that, regardless of corrective feedback types (in this case, individual and collaborative corrective feedback), corrective feedback has positive effect on EFL learners' writing ability in general.

Some English language teachers may be reluctant to correct and give feedback on students' writing tasks because of the large numbers of students in their classes and the limitation of time which deprives them to correct and discuss their mistakes. However, according to the findings of the present study, implementing collaborative corrective feedback could train the students themselves to correct and give feedback to each other. Different scholars in the area of language teaching and learning believe that Peer feedback gives students the opportunity to become more self-aware, to engage in self-reflection, self-expression and to contribute to decision making (Storch, 2005). In addition, collaborative corrective feedback seems to be enthusiastic and motivating for English learners, thus, integrating collaborative learning in EFL classes seems to make learners more willing to pursue classroom objectives.

Moreover, collaborative learning strategies can help students work with each other and produce final drafts of essays effectively. This idea has been supported by different scholars in the area of language teaching and learning such as, Hansen (2005, as cited in Albesher, 2012) and; Baker (2009, as cited in Albesher, 2012).

\section{References}

Ahmadi, S. M., \& Shekarabi, Z. (2014). The role of written corrective feedback in enhancing the linguistic accuracy of Iranian Japanese learners' writing. Iranian Journal of Language Teaching Research 2(1), 99-118.

Albesher, K. B. (2012). Developing the writing skills of ESL students through the collaborative learning strategy. Thesis submitted for the degree of Doctor of Philosophy in Education and Applied Linguistics. Newcastle University.

Ashwell, T. (2000). Patterns of Teacher Response to Student Writing in a Multiple- Draft Composition Classroom: Is Content Feedback Followed by Form Feedback the Best Method? Journal of Second Language Writing, 9(3), 227-257. https://doi.org/10.1016/S1060-3743(00)00027-8 
Ballester, C. P., \& Cabello, A. C. (2016). L2 Collaborative E-writing. Social and Behavioral Sciences 228,601 -607.

Bitchener, J. (2008). Evidence in support of written corrective feedback. Journal of Second Language Writing, 17(2), 102-118. https://doi.org/10.1016/j.jslw.2007.11.004

Brown, H. D. (2007). Teaching by Principles: An interactive approach to language pedagogy (2nd ed). New York: Longman.

Corpuz, V. (2011). Error correction in second language writing: Teachers' beliefs, practices, and students' preferences (Doctoral dissertation). Queenland University

of Technology, Faculty of Education. Retrieved from http://eprints.qut.edu.au/49160/

Farid, S., \& Samad, A. A. (2012). Effects of different kind of direct feedback on students' writing. Social and Behavioral Sciences, 66, 232-239. https://doi.org/10.1016/j.sbspro.2012.11.265

Farrokhi, F., \& Sattarpour, S. (2012). The effects of direct written corrective feedback on improvement of grammatical accuracy on "high-proficient L2 learners". World Journal of Education, 2(2), 49-57. https://doi.org/10.5430/wje.v2n2p49

Fawcett, L. M., \& Garton, A. F. (2005). The effect of peer collaboration on children's problem-solving ability. British Journal of Education Psychology, 75(2), 157-169. https://doi.org/10.1348/000709904X23411

James, C. (1998). Error in Language Learning and Use: Exploring Error Analysis. New York: Pearson Education Limited.

Lantolf, J. (2000). Second language learning as a mediated process. Language Teaching, 33, 79-96. https://doi.org/10.1017/S0261444800015329

Liu, J., \& Hansen, J. (2002). Peer response in second language writing classroom. Ann Arbor, MI: University of Michigan Press. https://doi.org/10.3998/mpub.8952

Marzban, A. (2014). Collaborative Negotiated Feedback versus Teacher-written Feedback: Impact on Iranian Intermediate EFL Learners Writing. Theory and Practice in Language Studies, 4(2), 293-302. https://doi.org/10.4304/tpls.4.2.293-302

Richards, J. C., \& Renandya, W. A. (2002). Methodology in language teaching: An anthology of current practice. Cambridge: Cambridge University Press. https://doi.org/10.1017/CBO9780511667190

Sarkhosh, M., Farahani, A. K., \& Soleimani, M. (2012). Different types of corrective feedback and the improvement of the accuracy in the use of English simple past. The Iranian EFL Journal, 8(6), 258-280.

Schmidt, R. (2001). Cognition and second language instruction. Attention. In P. Robinson (Ed.). Cambridge: Cambridge University Press.

Shull, J. T. (2001). Teaching the writing process to high school juniors through cooperative learning strategies, (Unpublished $\mathrm{PhD}$ Thesis). Walden University.

Soleimani, H. (2014). The impact of writing peer correction feedback on pre-intermediate Iranian EFL learners' writing performance. International Journal of Language Learning and Applied Linguistics World, 5(4), 1-10.

Storch, N. (2005). Collaborative writing: product, process, and students' reflections. Journal of Second Language Writing, 14(3), 153-173. https://doi.org/10.1016/j.jslw.2005.05.002

Storch, N., \& Wigglesworth, G. (2007). Writing tasks: The effects of collaboration, in Maria del Pilar \& Garcia Mayo (eds.) Investigating tasks in formal language learning, 157-177, Multilingual Matters Ltd, 157-177.

Suzuki, M. (2008). Japanese learners, self-revisions and peer revisions of their written compositions in English. TESOL Quarterly, 42(2), 209-233. https://doi.org/10.1002/j.1545-7249.2008.tb00116.x

Truscott, J. (2007). The effect of error correction on learners' ability to write accurately. Journal of Second Language Writing, 16(4), 255-272. https://doi.org/10.1016/j.jslw.2007.06.003

\section{Copyrights}

Copyright for this article is retained by the author(s), with first publication rights granted to the journal.

This is an open-access article distributed under the terms and conditions of the Creative Commons Attribution license (http://creativecommons.org/licenses/by/4.0/). 